\title{
Uji Efek Antibakteri Minyak Jintan Hitam (Nigella Sativa) Dalam Kapsul yang Dijual Bebas Selama Tahun 2012 di Kota Padang Terhadap Bakteri Staphylococcus aureus dan Escherichia coli Secara In Vitro
}

\author{
Gesza Utama Putra ${ }^{1}$, Aziz Djamal $^{2}$, Machdawaty Masri $^{3}$
}

\begin{abstract}
Abstrak
Jintan Hitam atau Nigella sativa diketahui memiliki kemampuan sebagai antibakteri, seperti terhadap Staphylococcus aureus dan Escherichia coli. Kedua bakteri ini memiliki sifat yang berbeda namun memiliki kesamaan dari penyakit yang disebabkannya. Tujuan penelitian ini adalah untuk membandingkan efek antibakteri produk minyak jintan hitam (Nigella sativa) dalam bentuk kapsul antara bakteri Staphylococcus aureus dan Escherechia coli secara in vitro. Penelitian ini dilakukan pada bulan Januari 2012 - Desember 2012 di Laboratorium Mikrobiologi, Fakultas Kedokteran Universitas Andalas. Penelitian ini menunjukkan bahwa semua sampel jintan hitam yang digunakan tidak memiliki efek antibakteri terhadap Escherichia coli dan semua sampel tersebut memiliki efek antibakteri yang bervariasi pada Staphylococcus aureus. Analisis Anova menunjukkan bahwa masing-masing sampel minyak Nigella sativa memberikan efek berbeda secara signifikan pada pertumbuhan Staphylococcus aureus, bahkan enam diantaranya memiliki efek yang lebih baik daripada Cepoperazon $(25 \mathrm{~mm}$ ) sebagai kontrol yang digunakan.
\end{abstract}

Kata kunci: Nigella sativa, efek antibakteri, Staphylococcus aureus, Escherichia coli.

\section{Abstract}

Black Cumin or Nigella sativa known have the capability as antibacterial, such as to Staphylococcus aureus and Escherichia coli. Both of these bacteria have different properties but have similarities from diseases they may cause. The objective of this study was to compare anti-bacterial effects of black cumin oil (Nigella sativa) which has been packaged in capsules towards Staphylococcus aureus and Escherichia coli in vitro The research was conducted in January 2012 to December 2012 at the Microbiology laboratory, Medicine Faculty of Andalas University. The results of this research indicate that all black cumin samples that are used did not have antibacterial effect against Escherichia coli and all samples had antibacterial effects on Staphylococcus aureus with germ-free area that size varies. Anova analysis results indicate that each of Nigella sativa gives differ effects significantly on Staphylococcus aureus growth, even six of them have better effect than Cepoperazon $(25 \mathrm{~mm})$ were used as controls.

Keywords: Nigella sativa, antibacterial effect, Staphylococcus aureus, Escherichia coli

Affiliasi penulis : 1. Pendidikan Dokter FK UNAND (Fakultas Kedokteran Universitas Andalas Padang), 2. Bagian Mirobiologi Klinik FK UNAND, 3. Bagian Kimia FK UNAND

Korespondensi : Gesza Utama Putra, E-mail :

geszautamaputra@gmail.com, Telp: 085274772773

\section{PENDAHULUAN}

Jintan hitam (Nigella sativa) selama ini telah lama digunakan sebagai obat alami untuk menyembuhkan penyakit, dan bijinya juga dijadikan bumbu dalam masakan. Minyak jintan hitam telah 
digunakan sejak 2000 hingga 3000 tahun sebelum masehi. Hal ini terbukti dengan ditemukannya minyak Nigella sativa dalam pekuburan Tutan-khamen (makam raja mesir kuno), yang biasa digunakan dalam praktik kehidupan Mesir Kuno. Dalam literatur kuno tercatat mengenai ahli pengobatan terdahulu yang meneliti tentang jintan hitam, seperti lbnu Sina dan Al-Biruni, Al-antiki, Ibnu Qayyim dan Al-Baghdadi. ${ }^{1}$

Jintan hitam (Nigella sativa) adalah sumber yang penting untuk asam lemak esensial, protein, karbohidrat dan vitamin serta mineral. Jintan hitam juga kaya akan sterol, terutama beta sitosterol, yang dikenal memiliki kemampuan mencegah kanker. Nigella sativa selama ini telah banyak digunakan sebagai obat alami untuk menyembuhkan penyakit, dan bijinya juga dijadikan bumbu dalam masakan. Dalam pengobatan tradisional, jintan hitam (Nigella sativa) digunakan sebagai obat-obatan diuretik, untuk mengobati sakit perut, hati dan saluran cerna. ${ }^{2,3}$

Berdasarkan berbagai penelitian sebelumnya, Nigella sativa mengandung dua unsur penting, yaitu Nigellone dan Thymoquinone. Nigellone merupakan suatu zat yang dapat menghambat terjadinya kejang pada otot dan spasme pada saluran pernapasan. Pada trakea Nigellone bersifat antispasmodik, kontraksi trakea di induksi oleh leukotriene-d yang di hambat oleh Nigellone dan Thymoquinone. Thymoquinone merupakan bahan aktif dari ekstrak minyak biji Nigella sativa, yang sebelumnya telah terbukti berfungsi sebagai antitumor, antioksidan dan anti inflamasi bioaktivitas. Ekstraksi Nigella sativa menghasilkan ekstrak minyak berwarna hijau dengan bau aromatik yang kuat. Delapan asam lemak diidentifikasi terkandung dalam ekstrak tersebut yang mewakili sekitar 99,5\% dari komposisi jumlah asam lemak. Ekstrak terdiri dari empat asam lemak jenuh $(17,0 \%)$ dan empat tak jenuh asam lemak (82,5\%). Asam linoleat $(55,6 \%)$, asam oleat $(23,4 \%)$, dan asam palmitat (12,5\%) adalah komponen utama. ${ }^{4-7}$

Staphylococcus aureus merupakan salah satu genus dari Staphylococcus. Identifikasi bakteri ini berdasarkan kemampuan mengkoagulasi plasma, karena Staphylococcus aureus satu-satunya golongan Staphylococcus yang memproduksi koagulase. Kuman ini bersifat invasif, penyebab hemolisis membentuk koagulasa, mencairkan gelatin, membentuk pigmen kuning emas, dan meragi manitol. Mudah tumbuh pada perbenihan bakteri dalam keadaan aerobik atau mikroaerofilik dengan temperature optimum $37^{\circ} \mathrm{C}{ }^{8}$

Escherichia coli adalah kuman oportunis yang banyak ditemukan di dalam usus besar manusia sebagai flora normal. Sifatnya unik karena dapat menyebabkan infeksi primer pada usus misalnya diare pada anak dan travelers diarrhea. Kemampuan menimbulkan infeksi pada jaringan tubuh lain di luar usus. Infeksi Escherichia coli patogen sangat bervariasi, dapar berupa: infeksi asimtomatik, diare tanpa darah, diare berdarah (hemorraghic colitis), SHU (sindrom hemolitik uremik), sampai kematian. ${ }^{8}$

Beberapa penelitian terhadap minyak jintan hitam yang diekstraksi langsung oleh penelitinya, terbukti minyak biji jintan hitam dapat menghambat bakteri Staphylococcus aureus yang menghasilkan zona daya hambat sebesar $15 \%$. Ekstrak ethanol dari jintan hitam dapat menghambat pertumbuhan bakteri Methicillin Resistant Staphylococcus aureus (MRSA). Hasil penelitian tentang efek antimikroba minyak jintan hitam (Nigella sativa) terhadap pertumbuhan Escherichia coli juga menunjukan bahwa minyak jintan hitam (Nigella sativa) terbukti bermakna secara statistik $(p<0,05)$ dalam menghambat pertumbuhan Escherichia coli. Semakin tinggi konsentrasi minyak jintan hitam maka zona hambatan yang terbentuk semakin besar pula, tetapi pengaruh minyak jintan hitam lebih lemah dibanding dengan kotrimoksazol kontrol positif. ${ }^{9-11}$

Meskipun telah cukup banyak penelitian yang menggunakan minyak jintan hitam sebagai variabel dalam penelitiannya, namun masih banyak perbedaan pendapat mengenai sifat antibakteri minyak tersebut, untuk itu perlu penelitian ini dilakukan dengan tujuan mengetahui efek antibakteri produk minyak jintan hitam (Nigella sativa) dalam bentuk kapsul yang dijual bebas di Kota Padang, Sumatera Barat terhadap bakteri Staphylococcus aureus dan Escherechia coli secara in vitro.

\section{METODE}

Penelitian ini dilakukan di laboratorium Mikrobiologi Fakultas Kedokteran Universitas Andalas Padang dari Januari sampai Desember 2012. Sampel adalah tujuh macam produk dagang minyak jintan 
hitam (Nigella sativa) yang dijual secara bebas di Kota Padang pada tahun 2012 dengan menggunakan metode analitik eksperimental. Variabel adalah minyak jintan hitam (Nigella sativa) dalam tujuh produk yang berbeda dan bakteri Staphylococcus aureus dan Escherichia coli. Alat yang digunakan adalah cawan petri, kertas saring, jarum ose, bunsen spritus, tabung reaksi, lidi kapas steril, pinset, otoklaf, inkubator, dan tabung kaca steril. Bahan yang digunakan adalah minyak jintan hitam dari tujuh produk yang berbeda, biakan murni Staphylococcus aureus dan Escherichia coli, $\mathrm{NaCl}$ 0,9\%, alkohol 70\%, dan agar Mueller Hinton. Penelitian dilakukan dengan meletakan kertas saring yang telah direndam menggunakan masingmasing minyak jintan hitam dan diletakkan dalam sebuah cawan petri yang telah ditanamkan Staphylococcus aureus dan Escherichia coli. Perlakuan terhadap masing-masing bakteri dilakukan sebanyak tiga kali. Sebagai kontrol untuk pembanding efek antibakteri yang akan didapatkan, digunakan antibiotik Cepoperazon yang memberikan daya hambat dengan diameter $10 \mathrm{~mm}$ terhadap Escherichia coli dan $25 \mathrm{~mm}$ terhadap Staphlococcus aureus.

\section{HASIL}

Tabel 1. Diameter daerah bebas pertumbuhan Escherichia coli.

\begin{tabular}{cccccc}
\hline No & $\begin{array}{c}\text { Nama } \\
\text { Sampel }\end{array}$ & \multicolumn{3}{c}{ Perlakuan } & $\begin{array}{c}\text { Rerata } \\
(\mathbf{m m})\end{array}$ \\
\hline 1 & & 1 & 2 & 3 & \\
\hline 2 & A & - & - & - & - \\
\hline 3 & B & - & - & - & - \\
\hline 4 & C & - & - & - & - \\
\hline 5 & D & - & - & - & - \\
\hline 6 & E & - & - & - & - \\
\hline 7 & G & - & - & \\
\hline Keterangan: tanda “-“ menunjukan tidak terdapat zona bebas \\
kuman.
\end{tabular}

Tabel 1 memperlihatkan bahwa pengujian terhadap Escherichia coli tidak memiliki zona bebas kuman yang diartikan tidak terdapat efek antibakteri dari minyak jintan hitam yang diujicobakan terhadap Escherichia coli.
Tabel 2. Diameter daerah bebas pertumbuhan Staphylococcus aureus

\begin{tabular}{cccccc}
\hline No & Nama & \multicolumn{3}{c}{ Perlakuan } & $\begin{array}{c}\text { Percobaan } \\
\text { Tunggal } \\
\end{array}$ \\
\cline { 3 - 5 } Sampel & $\mathbf{1}$ & $\mathbf{2}$ & $\mathbf{3}$ & \begin{tabular}{c} 
(mm) \\
\hline 1
\end{tabular} \\
& A & 10 & 10 & $\sim$ & 9 \\
\hline 2 & B & $\sim$ & $\sim$ & $\sim$ & $\sim$ \\
\hline 3 & C & $\sim$ & $\sim$ & $\sim$ & 70 \\
\hline 4 & D & $\sim$ & $\sim$ & $\sim$ & 73 \\
\hline 5 & E & $\sim$ & $\sim$ & $\sim$ & $\sim$ \\
\hline 6 & F & $\sim$ & $\sim$ & $\sim$ & 90 \\
\hline 7 & G & $\sim$ & $\sim$ & $\sim$ & $\sim$
\end{tabular}

Keterangan : Percobaan tunggal hanya menggunakan satu jenis kapsul Nigella sativa terhadap satu lempeng cawan petri

Lambang " " menyatakan bahwa daerah bebas kuman tidak dapat diukur karena melebihi diameter cawan petri/tidak terdapat pertumbuhan bakteri pada cawan petri.

Pengujian terhadap Staphylococcus aureus didapatkan hasil yang berbanding terbalik dengan pengujian terhadap Escherichia coli. Peneliti tidak menemukan adanya perkembangbiakan dari Staphylococcus aureus yang telah ditanam sebelumnya. Dari hasil tersebut, peneliti melakukan pengulangan dengan meletakan satu jenis sampel pada satu cawan petri yang telah ditanami Staphylococcus aureus, dengan tujuan agar dapat menilai zona bebas kuman dari masing-masing jenis sampel (percobaan tunggal).

Perlakuan terhadap Staphylococcus aureus didapatkan hasil yang tercantum pada Tabel 2. Hasil penelitian tersebut diolah menggunakan uji statistik dengan menggunakan metode One Way Anova dengan hasil analisis menunjukkan bahwa masingmasing Nigella sativa memberikan efek yang berbeda secara signifikan terhadap pertumbuhan bakteri Staphylococcus aureus. Hal ini ditunjukkan oleh hasil analisis Anova yang memberikan nilai uji $\mathrm{F}$ sebesar 4,00 dan nilai signifikansi sebesar 0,15 (lebih kecil dari 0,05$)$.

\section{PEMBAHASAN}

Penelitian ini mengambil tujuh macam sampel jintan hitam dari merek dagang yang berbeda yang 
dijual bebas di kota Padang selama tahun 2012. Untuk mendapatkan hasil yang baik dalam tujuan pengobatan, minyak jintan hitam harus didapatkan dari proses pengolahan yang tepat. Kondisi lahan pengolahan seperti kualitas tanah dan intensitas cahaya matahari mempunyai pengaruh yang besar terhadap kualitas jintan hitam, begitu pula kelayakan pada saat panen dan proses cold pressing yang umumnya digunakan sebagai cara pengolahan untuk mendapatkan minyak jintan hitam tersebut juga akan mempengaruhi kondisi dari bahan obat yang terkandung dalam jintan hitam. Informasi tersebut dapat menjadi faktor yang membedakan kemampuan efek antibakteri jintan hitam dari berbagai produk yang berbeda.

Seluruh produk yang diujicobakan tidak memiliki efek antibakteri terhadap Escherechia coli, namun seluruh produk tersebut memiliki perbandingan efek terhadap Staphylococus aureus. Hasil penelitian membuktikan bahwa enam buah minyak jintan hitam (jintan hitam B s/d G) memiliki efek antibakteri yang luas, dengan diameter daya hambat $70 \mathrm{~mm}$ hingga sama atau lebih dari $90 \mathrm{~mm}$ (sama dengan diameter cawan petri). Diasumsikan sama atau lebih dari diameter cawan petri karena pada cawan petri tersebut tidak tumbuh Staphylocccus aureus yang telah ditanam sebelumnya. Hasil tersebut diambil dari pengujian kedua yang menggunakan satu cakram pada satu cawan petri.

Tabel 1 dan 2 menunjukan bahwa ketujuh jintan hitam tidak memperlihatkan diameter daerah bebas kuman ketika diuji dengan Escherichia coli tetapi seluruh produk jintan hitam yang diujicobakan memiliki efek antibakteri terhadap Staphylococcus aureus dengan diameter yang bervariasi. Diameter daerah bebas kuman yang terbesar terdapat pada cawan petri B, E, dan $\mathrm{G}$ dengan daerah bebas kuman yang sama atau lebih dari diameter cawan petri sehingga tidak terdapat kuman yang tumbuh pada cawan tersebut. Diameter daerah bebas kuman terkecil terdapat pada jintan hitam yang berada pada cawan petri A dengan diameter $9 \mathrm{~mm}$.

Hasil penelitian ini juga didukung dengan uji statistik yang menunjukan bahwa efek antibakteri ketujuh macam produk jintan hitam terhadap
Staphylococcus aureus adalah signifikan. Hal ini bisa disebabkan oleh jenis bibit yang digunakan sebagai bahan baku dari masing-masing produk berbeda varietasnya, ataupun kondisi lahan pengolahan yang tidak sama perlakuannya terhadap masing-masing jintan hitam yang menjadi bahan baku dari seluruh produk tersebut. Proses pengolahan pasca panen juga akan mempengaruhi hasil akhirnya.

Penelitian sebelumnya yang dilakukan untuk mengetahui efek antibakteri Nigella sativa dari hasil ekstraksi langsung telah diketahui hasil yang berbeda untuk setiap konsentrasi minyak yang diujicobakan terhadap Escherichia coli. Pada percobaan tersebut didapatkan hasil yang menunjukan bahwa minyak jintan hitam (Nigella sativa) mampu menghambat pertumbuhan Escherichia coli pada konsentrasi $100 \%$, $75 \%$, dan $50 \%$, sementara pada konsentrasi $25 \%$ tidak mampu menghambat pertumbuhan Escherichia coli. ${ }^{10}$

\section{KESIMPULAN}

Sampel minyak jintan hitam yang diujicobakan tidak memiliki kemampuan efek antibakteri terhadap Escherichia coli namun memiliki kemampuan efek antibakteri terhadap Staphylococcus aureus dengan diameter daerah bebas kuman yang berbeda serta enam dari tujuh sampel minyak jintan hitam memiliki efek antibakteri yang lebih baik dari cepoperazon yang digunakan sebagai kontrol pada pengujian terhadap Staphylococcus aureus.

\section{DAFTAR PUSTAKA}

1. Rizema SP. Mukjizat dan seluk beluk habbatussada'. Yogyakarta: Laksana; 2012.

2. Michael. Planetary herbalogy. Twin Lakes: Lotus Press;1992.

3. Anwar-ul Hasan, Gilani. A review of medicinal uses and pharmacological activities of nigella sativa. Pakistan Journal of Biological Sciences. 2004;7:441-51.

4. Herlina W. Jintan hitam menyembuhkan segala penyakit kecuali kematian. Yogyakarta: Media Presindo;2012.

5. Lei X, Liu M, Yang Z, Ji M, Guo X, Dong W. Thymoquinone prevents and ameliorates dextran sulfate sodium-induced colitis in mice. US 
National Library of Medicine National Institutes of Health. Tersedia dari: URL: HYPERLINK http:// www.ncbi.nlm.nih.gov;2012

6. Wienkötter N, Höpner D, Schütte $U$, Bauer K, Begrow F, El-Dakhakhny M, et al. The effect of nigellone and thymoquinone on inhibiting trachea contraction and mucociliary clearance. US National Library of MedicineNational Institutes of Health. Tersedia dari: URL: HYPERLINK http://www.ncbi.nlm.nih.gov;2008

7. Mozaffari FS, Ghorbanli M, Babai A, Farzami Sepehr M. The effect of water stress on the seed oil of Nigella sativa L. J. Essent. Oil Res. 2000; 12:36-8.
8. Jawetz E, Melnick, Adelberg. Mikrobiologi kedokteran. Jakarta: EGC;1996.

9. Ali, Basbulbul, G, Aydin T. Antimitotic and antibacterial effects of the Nigella sativa L. Seed. Caryologia. 2007;60(3): 270-2.

10. Asniyah. Efek Antimikroba minyak jintan hitam (nigella sativa) terhadap pertumbuhan escerichia coli in vitro. Jurnal Biomedika. 2009;1(1):25-9.

11. Hannan A, Saleem S, Chaudhary S, Barkaat M, Arshad MU. Anti bacterial activity of Nigella sativa against clinical isolates of methicillin resistant Staphylococcus aureus. J Ayub Med Coll Abbottabad. 2008;20(3):72. 